\title{
INVESTIGACIÓN
}

\section{Evolution of biometric parameters and chemical composition of olives from the Moroccan Picholine variety during fruit ripeness}

\author{
By H. Ajana (1), A. El Antari ${ }^{\star}$ (2) and A. Hafidi (1) \\ (1) Laboratoire Associé Francophone Sciences des Aliments, Departement de Biologie, \\ Faculté des Sciences Semlalia. Marrakech B.P. s/15. \\ (2) Laboratoire de la Technologie des Huiles, Programme - Olivier, Institut National de la \\ Recherche Agronomique. Marrakech, B.P. 533.
}

\section{RESUMEN}

Evolución de parámetros biométricos y composición química de aceitunas de la variedad Picholine marroquí durante la maduración del fruto.

La evolución del índice de madurez durante la maduración de aceitunas de la variedad Picholine marroquí no mostró variación significativa antes de mediados de septiembre. Después de esta fecha comenzó el crecimiento y alcanzó su valor máximo (4.7) a mediados de enero. El peso de las aceitunas aumentó continuamente desde junio hasta noviembre y se estabilizó durante dos meses más allá del valor máximo de $3.95 \mathrm{~g}$ (noviembre y diciembre). El peso del hueso de las aceitunas permaneció constante durante todo el período de muestreo. Las dimensiones de las aceitunas (longitud y anchura) tuvieron tendencias similares a las del peso de la aceituna.

La fracción lipídica polar del aceite predominó sobre la neutra durante los meses de junio y julio, para después de esta fecha prevalecer la fracción neutra alcanzando su valor máximo en el mes de diciembre. El contenido en proteína disminuyó de 4.6 a $2.3 \%$. El contenido en ceniza aumentó de 2.72 a $5.57 \%$. El contenido en clorofila en los aceites disminuyó progresivamente y mostró una correlación inversa con el índice de madurez. El contenido en fósforo disminuyó hasta septiembre y luego se conservó constante.

PALABRAS-CLAVE: Aceituna - Composición química - Maduración - Parámetro biométrico - Variedad Picholine marroquí.

\section{SUMMARY}

Evolution of biometric parameters and chemical composition of olives from the Moroccan Picholine variety during fruit ripeness.

The evolution of the maturity index during the ripeness of olives from the Moroccan Picholine variety did not show any significant variation before the middle of September. After this date it began the growing and reached the maximum value (4.7) at the middle of January. The weight of olives increased continuously from June to November, and remained constant over two months beyond the maximal value of $3.95 \mathrm{~g}$ (November and December). The weight of the olive kernels was constant during all the sampling period. The olive dimensions (length and width) showed similar trend as the olive weight.

The polar lipid fraction of the oil predominated over the neutral one during June and July, and after this date, the neutral fraction prevailed. The maximum value was reached in December. The protein content decreased from 4.6 to $2.3 \%$. Ash content grow from 2.72 to $5.57 \%$. The chlorophyll content in the oils decrease progressively and showed an inverse correlation with the maturity index. The phosphorus content diminished until September and then continued to be constant.

KEY-WORDS: Biometric parameter - Chemical composition Moroccan Picholine variety - Olive - Ripeness.

\section{INTRODUCTION}

Moroccan olive oil annual production is estimated to $45000 \mathrm{t}$, this represent only $10 \%$ to $15 \%$ of the national consumption of vegetable edible oils (M.A.M.V.A., 1996). Comparatively to other mediterranean olive oil producing counties, this production is low. Also a great part of the produced oils are of poor quality because of their high acidity and bad organoleptic properties. They are classed as lampantes olive oils which are not suitable for human consumption according to the International Olive Oil Council recommendations.

The sources of these quantity and quality problems are numerous, and are to search along the whole production process. The agricultural techniques, time of harvest, harvest and storage conditions, oil extraction techniques and its storage conditions are among the main factors.

The aim of this work is to determine the period of full ripeness of olives from the moroccan Picholine variety (which variety that represents $90 \%$ of olive trees) in the Marrakech area. At that time, olives must have a maximal rate of a good quality oil. 


\section{MATERIALS AND METHODS}

Sampling: It was conducted in a private farm in the outscurts of Marrakech. This area represents ca $24 \%$ of the whole national surface occupied by olive tree (M.A.M.V.A., 1996). Trees which had been used for sampling are well treated. The density of plantation is very low: 55 trees/ha. Because of the low raining (200 to $300 \mathrm{~mm} /$ year), olive-trees are regularly watered every fortnight. Fertilisation is practised twice a year (2 to 4 $\mathrm{Kg} / \mathrm{tree}$ ): just after harvest with the Urea 46 and at June-July with the Potase 33 . The sampling period has began from June the $6^{\text {th }}$ and lasted until February the $2^{\text {nd }}$ (13 samples were collected). Samples were analysed as follows.

Samples characterization: Weight, length and width of the olives and weight of kernel were determined in 100 randomly chosen fruits.

The maturity index (MI) was calculated after a visual colour appreciation over a hundred randomly-chosen olives according to the following formula.

$$
\mathrm{IM}=(\mathrm{a} \times 0)+(\mathrm{b} \times 1)+(\mathrm{c} \times 2)+(\mathrm{d} \times 3)+(\mathrm{e} \times 4)+(\mathrm{f} \times 5)+
$$$$
(\mathrm{g} \times 6)+(\mathrm{h} \times 7) / 100
$$

Where $a, b, \ldots . h$ are the number of the olives in each of the seven colour classes which begin from the dark green to the dark black.

Olives analyses: Moisture and ashes in total olive fruit were determined using $1 \mathrm{~g}$ of olive paste according to the AFNOR methods, NF. V. 03-903 and NF. T. 60-209 respectively, (AFNOR, 1984). Protein content was calculated after total nitrogen determination by the Kjeldhal method (NF. V. 18-100), but using a mixed catalyst according to Albat (Albat, 1982).

Oil extraction: It was carried out with hexane (soxhlet) using the modified Folch method (Marzouk et al., 1981). The crushed olives (20g of olive) (with an IKA Universalmûhle M20 moulder) were extracted three times for 20 minutes. Filtrates obtained after each extraction were mixed and washed with water. The extracted lipids were weighed after solvent removing under reduced pressure.

For the extraction with hexane, the crushed olives were put at $60^{\circ} \mathrm{C}$ for $3 \mathrm{~h}$, then, the oil was extracted in a soxhlet apparatus.

Neutral and polar lipids separation: An hexane methanol $(1: 1)$ mixture was added to the modified Folch extracted lipids. After agitation and decantation at $4^{\circ} \mathrm{C}$, neutral lipids in the upper organic phase were separated from the polar lipids in the methanol phase (Marzouk et al., 1981).

Oil analyses: Phosphorus determination was fulfilled according to the vanadomolybdic method (NF. T. 60-277) (AFNOR, 1984). Chlorophylls were estimated using a spectrophotometric method (Wollf, 1968). Assays were duplicated. Data are average of two determinations.

\section{RESULTS AND DISCUSSIONS}

\subsection{Evolution of the maturity index.}

The maturity index of fruits is an important criteria for estimating the harvest best-time. This index is colour-based. This latter changes during ripeness either for the epicarp and the mesocarp. This parameter shows no evolution during the two first months of our sampling (June $6^{\text {th }}$ - August $15^{\text {th }}$ ) (Table I). In this period, all olives had a dark-green colour, which started disappearing from September. From September $16^{\text {th }}$, the maturity index begun to increase and reaches its maximum during the last sampling month (January) (Table I).

Table I

Maturity index, fruit and kernel weight changes

\begin{tabular}{ccccc}
\hline $\begin{array}{c}\text { Dates of } \\
\text { sampling }\end{array}$ & $\begin{array}{c}\text { Maturity } \\
\text { Index }\end{array}$ & $\begin{array}{c}\text { Olives Weight } \\
(0 . \mathrm{W})(\mathrm{g})\end{array}$ & $\begin{array}{c}\text { Kernels weight } \\
(\mathrm{K} . \mathrm{W})(\mathrm{g})\end{array}$ & O.W/K.W \\
\hline $6 / 6$ & 0 & $0.88 \pm 0.1$ & - & - \\
$13 / 7$ & 0 & $2.36 \pm 0.1$ & $0.55 \pm 0.06$ & 4.29 \\
$15 / 8$ & 0 & $2.21 \pm 0.3$ & - & - \\
$16 / 9$ & 0 & $2.60 \pm 0.4$ & $0.54 \pm 0.07$ & 4.80 \\
$5 / 10$ & 0.17 & $2.86 \pm 0.4$ & $0.53 \pm 0.09$ & 5.39 \\
$16 / 10$ & 0.84 & $3.11 \pm 0.6$ & $0.53 \pm 0.07$ & 5.80 \\
$1 / 11$ & 1.76 & $3.95 \pm 0.5$ & $0.52 \pm 0.07$ & 7.60 \\
$16 / 11$ & 2.33 & $3.81 \pm 0.7$ & $0.50 \pm 0.07$ & 7.60 \\
$3 / 12$ & 2.38 & $3.46 \pm 0.6$ & $0.51 \pm 0.07$ & 6.80 \\
$17 / 12$ & 3.06 & $3.91 \pm 0.8$ & $0.49 \pm 0.09$ & 7.90 \\
$2 / 1$ & 3.74 & $3.86 \pm 0.6$ & $0.55 \pm 0.08$ & 7.02 \\
$16 / 1$ & 4.76 & $3.49 \pm 0.5$ & $0.57 \pm 0.07$ & 6.10 \\
$2 / 2$ & 4.55 & $3.42 \pm 0.4$ & - & - \\
\hline
\end{tabular}

\subsection{Evolution of biometric parameters.}

Weight and dimensions (length and width) of ripe fruits are reported to be varietal caracteristics (Loussert et al., 1978). They are of a great importance in trade value determination of olives and their destination (oil production or table olives) (Kiritsakis et al., 1987).

Results in Table I show that the average weight of olive which was only of $0.88 \mathrm{~g}$ at the first sampling date increased rapidly and reached $2.36 \mathrm{~g}$ at the end of the same month. This trend continued but in a less fast way until November the $1^{\text {st }}$. By this time, olives reached their maximal weight (ca $3.95 \mathrm{~g}$ ). In the period between June the $6^{\text {th }}$ and November the $1^{\text {st }}$, the tissue multiplication was important and contributed, with the synthetized products, to the increase of the fruit weight.

As shown in Table I, the weight of olives reached its maximum $(3.95 \mathrm{~g})$ in November the $1^{\text {st }}$ and remained relatively stable during the next two months. After that, the weight begins to decrease 
slightly and reached the value of $3.42 \mathrm{~g}$ at the end of our sampling period. This can be a result of water loss due to ageing.

These results were similar to those reported by Atouati, who found a weight of $3.03 \mathrm{~g}$ for ripe olives in the Marrakech area (Atouati, 1991). But in the same region, variations can be attributed to agricultural practices. In all the sampling period, the olive kernel weight does not show any remarkable variation (0.50-0.55g). In fact, the kernel had already reached its final dimensions at the beginning of our sampling. After July the growing in olive weights was only due to the mesocarp development. The quotient, weight of olives to kernel weight evolved similarly as for the olives weight. This quotient grew continuously from the beginning of our sampling and reached a maximum (7.6-7.9) between November $1^{\text {st }}$ to December $17^{\text {th }}$. This supposed both a growth and a metabolic stability. Using this criteria for olives in Marrakech, such period would be between the beginning September and mid December.

Length and width showed similar evolution (Table II). The variations were similar to those of olives weight. These dimensions grew progressively and reached, as the olives weight, a maximum at the beginning of November $(L=2.34 \mathrm{~cm} ; W=1.69 \mathrm{~cm})$. A slight decrease caused by deshydratation, was observed from January $16^{\text {th }}$.

Table II

Changes of the fruit dimensions

\begin{tabular}{ccc}
\hline Dates of sampling & Lenght $(\mathrm{cm})$ & Width $(\mathrm{cm})$ \\
\hline $6 / 6$ & $1.74 \pm 0.2$ & $0.96 \pm 0.1$ \\
$13 / 7$ & $2.03 \pm 0.2$ & $1.35 \pm 0.2$ \\
$15 / 8$ & $2.06 \pm 0.1$ & $1.32 \pm 0.1$ \\
$16 / 9$ & $2.10 \pm 0.1$ & $1.43 \pm 0.1$ \\
$5 / 10$ & $2.18 \pm 0.1$ & $1.50 \pm 0.1$ \\
$16 / 10$ & $2.15 \pm 0.2$ & $1.54 \pm 0.1$ \\
$1 / 11$ & $2.34 \pm 0.1$ & $1.69 \pm 0.1$ \\
$16 / 11$ & $2.28 \pm 0.2$ & $1.66 \pm 0.1$ \\
$3 / 12$ & $2.24 \pm 0.1$ & $1.64 \pm 0.1$ \\
$17 / 12$ & $2.26 \pm 0.4$ & $1.64 \pm 0.1$ \\
$2 / 1$ & $2.30 \pm 0.1$ & $1.66 \pm 0.1$ \\
$16 / 1$ & $2.24 \pm 0.2$ & $1.61 \pm 0.1$ \\
$2 / 2$ & $2.22 \pm 0.1$ & $1.54 \pm 0.1$ \\
\hline
\end{tabular}

The maturity index, the olives weights and dimensions showed similar evolutions. A good correlation between these parameters $(r=0.98)$ was observed in the period between November $1^{\text {st }}$ and January $2^{\text {nd }}$. In this period the olive fruits showed their maximal dimensions and the quotient $L W$ was $>0.72$, in good agreement with results found by Loussert et al. (1978). This period could be considered as the period of full ripeness.

However, these biometric parameters wouldn't be sufficient for the determination of the best harvest period. The chemical composition of olives, their oil content and quality must also be considered.

\subsection{Chemical composition of olives}

Evolution of water contents: Water content of olives grew continuously during the first three samples (Table III). After that (from August $15^{\text {th }}$ to November $1^{\text {st }}$ ) it showed a relative stability around a value of $39 \%$. The water content was closely related to water supplying (irrigation, raining) and to the temperature. This first stability period occurred in droughty months, critical period in which water supplying is indispensable for a good development of olive fruits (Poli, 1986). The water content grew rapidly from the beginning of November and reached $60 \%$ at November the $16^{\text {th }}$. Them a slight diminution was observed and the water content stabilised around 55\% $\left(\right.$ December $3^{\text {rd }}$ ). This second stability phase occurred in a relatively rainy months and low temperatures.

Table III

Water and protein content changes

\begin{tabular}{cccc}
\hline $\begin{array}{c}\text { Dates of } \\
\text { sampling }\end{array}$ & $\begin{array}{c}\text { Water } \\
\text { content (\%) }\end{array}$ & \multicolumn{2}{c}{ Protein (\%) } \\
\hline $6 / 6$ & 29.88 & 4.6 & 5.7 \\
$13 / 7$ & 34.69 & 3.5 & 4.6 \\
$15 / 8$ & 39.07 & 3.4 & 4.6 \\
$16 / 9$ & 39.50 & 3.5 & 5.1 \\
$5 / 10$ & 40.12 & 3.7 & 5.4 \\
$16 / 10$ & 39.75 & 4.1 & 5.8 \\
$1 / 11$ & 38.82 & 3.5 & 5.1 \\
$16 / 11$ & 60.26 & 2.5 & 4.3 \\
$3 / 12$ & 55.16 & 2.7 & 5.0 \\
$17 / 12$ & 55.32 & 2.3 & 4.0 \\
$2 / 1$ & 53.62 & 2.6 & 4.6 \\
$16 / 12$ & 52.13 & 3.2 & 5.5 \\
$2 / 2$ & 49.77 & 2.9 & 4.8 \\
\hline
\end{tabular}

Changes of protein contents: Protein content in olives changed with time (Table III). It decreased from $4.6 \%$ of fresh matter in the first sample to $2.3 \%$ at the end of the sampling period. Kiristakis (1987) reported a similar evolution.

Changes of ash content: Ash content (Table IV) in dry matter was stable between June the $6^{\text {th }}(2.72 \%)$ and August $15^{\text {th }}(2.67 \%)$. Then it increased. From September the $16^{\text {th }}$ to February the $2^{\text {nd }}$, a relatively 
important content of ashes was observed, being 5\% of the dry matter of olives.

Table IV

Ash contents changes

\begin{tabular}{ccc}
\hline \multirow{2}{*}{ Dates of sampling } & \multicolumn{2}{c}{ Ash content (\%) } \\
& fresh matter & dry matter \\
\hline $6 / 6$ & 2.72 & 0.87 \\
$13 / 7$ & 2.69 & 0.75 \\
$15 / 8$ & 2.67 & 0.83 \\
$16 / 9$ & 3.06 & 1.04 \\
$5 / 10$ & 3.23 & 1.13 \\
$16 / 10$ & 3.78 & 1.27 \\
$1 / 11$ & 4.4 & 1.56 \\
$16 / 11$ & 4.5 & 1.98 \\
$3 / 12$ & 5.05 & 2.37 \\
$17 / 12$ & 4.65 & 2.16 \\
$2 / 1$ & 5.07 & 2.34 \\
$16 / 1$ & 5.46 & 2.44 \\
$2 / 1$ & 5.57 & 2.33 \\
\hline
\end{tabular}

Changes of oil content: Oil content of olives increased continuously along the sampling period up to the beginning of December (2\% in June, $34 \%$ in December). Oil content stabilized beyond a maximal value and then decreased slightly in the two last samples (Table V).

Table $\mathrm{V}$

The modified Folch extracted oil content evolution

\begin{tabular}{cc}
\hline Dates of sampling & Oil content $(\%)$ \\
\hline $6 / 6$ & 2.2 \\
$13 / 7$ & 4.1 \\
$15 / 8$ & 6.2 \\
$16 / 9$ & 12.1 \\
$5 / 10$ & 13.9 \\
$16 / 10$ & 11.0 \\
$1 / 11$ & 16.1 \\
$16 / 11$ & 18.6 \\
$3 / 12$ & 33.8 \\
$17 / 12$ & 30.5 \\
$2 / 1$ & 31.9 \\
$16 / 1$ & 28.4 \\
$2 / 2$ & 22.4 \\
\hline
\end{tabular}

The modification of the Folch system proposed by Marzouk concerns the second step of extraction where an hexane-methanol replaces the chloroformmethanol mixture and the extracts are washed with water at the end. This treatment would eliminate any hydrosoluble components (proteins, sugars, phospholipids....).

Our results show that olives from the Moroccan Picholine contained, in December and January, the greatest quantities of oil. The Moroccan Picholine is reported to contain 19 to $25 \%$ of oil (Loussert and Brousse, 1978 and Walali et al. 1984). These rates vary depending on the region, the climate, and the agricultural techniques. The quantity of the oil extracted does depend also on the extraction technique (centrifuging or press) (Atouati, 1991 and Di Giovacchino, 1991).

Evolution of neutral and polar lipids: There was a dominance of polar lipids in the two first samples. Neutral lipids proportions grew progressively, and by September $16^{\text {th }}$, they represented two times the rates of the polar lipids (Table $\mathrm{VI}$ ). From beginning December to mid January, they varied between 25 to $29 \%$. A decrease in proportions on neutral lipids was observed at the end of our sampling period ( $2^{\text {nd }}$ February). Oil contents obtained by the hexane extraction (soxhlet) were lower than those obtained by the modified Folch system (Table VI), but they are almost comparable to those of the neutral lipids from the modified Folch system. In fact, as hexane is an apolar solvent, it extracts more easily the neutral oil.

Table VI

Changes neutral and polar lipids rates

\begin{tabular}{cccc}
\hline Samples & \multicolumn{2}{c}{ Modified Folch (\%) } & $\begin{array}{c}\text { Soxhlet } \\
\text { Neutral lipid (\%) }\end{array}$ \\
& N.L & P.L & \\
\hline $6 / 6$ & 0.20 & 1.9 & 0.39 \\
$13 / 7$ & 1.40 & 2.5 & 1.85 \\
$15 / 8$ & 3.70 & 2.5 & 3.95 \\
$16 / 9$ & 6.80 & 3.3 & 9.60 \\
$5 / 10$ & 11.4 & 2.6 & 11.4 \\
$16 / 10$ & 8.70 & 2.3 & 13.3 \\
$1 / 11$ & 14 & 2.1 & 17.8 \\
$16 / 11$ & 16.2 & 2.5 & 17.9 \\
$3 / 12$ & 29.3 & 4.5 & 21.8 \\
$17 / 12$ & 25.9 & 4.6 & 19.9 \\
$2 / 1$ & 29.1 & 2.8 & 22.3 \\
$16 / 1$ & 24.9 & 3.5 & 23.1 \\
$2 / 1$ & 19.7 & 2.7 & 17.47 \\
\hline
\end{tabular}

N.L $=$ Neutral lipid $\quad$ P.L $=$ Polar lipid 
Estimation of the full ripeness period: Olives contain maximal quantities of oil from the beginning of December until the end of January (Table VI). This period must be the most appropriate for harvest.

\subsection{Properties of the extracted oils}

Phospholipids changes: Rates of phosphorus (Table VII) showed high values in the first samples (300 ppm) for the modified Folch extracted oils. In this phase the total lipids were mainly composed by polar lipids. From September, phosphorus content decreased below $160 \mathrm{ppm}$. These results are comparable to those reported by Kiritsakis et al., (1987). The phosphorus content of oil depend on the variety, the ripeness level of the fruit, the extraction conditions, the nature of the soil and climate (Alter et al., 1982).

Table VII

\section{Changes of the oils phosphorus contents (ppm)}

\begin{tabular}{ccc}
\hline $\begin{array}{c}\text { Dates of } \\
\text { sampling }\end{array}$ & $\begin{array}{c}\text { Modified Folch } \\
\text { system }\end{array}$ & $\begin{array}{c}\text { Hexane } \\
\text { (soxhlet) }\end{array}$ \\
\hline $6 / 6$ & 356 & - \\
$13 / 7$ & 298 & - \\
$15 / 8$ & 208 & - \\
$16 / 9$ & 113.31 & 126.96 \\
$5 / 10$ & 151.18 & - \\
$16 / 10$ & 135.87 & 76.68 \\
$1 / 11$ & 159.33 & 62.04 \\
$16 / 11$ & 110.32 & 33.56 \\
$3 / 12$ & 146.64 & 49.06 \\
$17 / 12$ & 124 & 57.13 \\
$2 / 1$ & 144.45 & 68.25 \\
$16 / 1$ & 138.7 & 48.59 \\
$2 / 1$ & 152 & 72.63 \\
\hline
\end{tabular}

The hexane does not extracted high level of phospholipids. The phosphorus contents of hexane extracted oil varied between 25 and 70 ppm.

In the case of pression extracted olive oil, it generally contains low amounts of phospholipids. A low phosphorus content is always desirable because during storage the phospholipids precipitates making inconvenient aspects of the oil.

Chlorophylls content changes: The evolution of the chlorophyll content during the ripeness of olives (Table VIII) continuously decreased. This agrees perfectly with other reported data (MínguezMosquera et. al, 1990). The chlorophyll contents in the oil depends on the ripeness level of the olives. The modified Folch system extracted oil contained the highest levels of chlorophylls $(\geq 100 \mathrm{ppm})$ during the period between June the $6^{\text {th }}$ and October the $5^{\text {th }}$.
In this period the maturity index did not exceed a value of 1 . After this period, an important and continuous decrease was observed since October the $16^{\text {th }}$. In the last sample, chlorophylls represented only $0.9 \mathrm{ppm}$. The hexane extracted oils had less chlorophylls than the modified Folch extracted oils. But, a similar evolution was observed. In January these contents were reduced to a zero value.

Table VIII

Changes of the chlorophyll contents in the extracted oils (ppm)

\begin{tabular}{ccc}
\hline $\begin{array}{c}\text { Dates of } \\
\text { sampling }\end{array}$ & $\begin{array}{c}\text { Modified Folch } \\
\text { system }\end{array}$ & $\begin{array}{c}\text { Hexane } \\
\text { (soxhlet) }\end{array}$ \\
\hline $6 / 6$ & 284.6 & - \\
$13 / 7$ & 149.9 & - \\
$15 / 8$ & 102.3 & - \\
$16 / 9$ & 117.9 & - \\
$5 / 10$ & 90.8 & 43.9 \\
$16 / 10$ & 67 & 46.1 \\
$1 / 11$ & 22.2 & 16.8 \\
$16 / 11$ & 35.3 & 6.5 \\
$3 / 12$ & 8.1 & 11.2 \\
$17 / 12$ & 5.3 & 2.3 \\
$2 / 1$ & 0.3 & 0 \\
$16 / 1$ & 0.2 & 0 \\
$2 / 1$ & 0.9 & 0 \\
\hline
\end{tabular}

Changes of the chlorophyll contents was inverted to that of the maturity index. These two parameters are depending on the proportion of the green olives. The degradation of chlorophy.lls to pheophytins causes the vanishing of the green colour (Aitzetmüller, 1989) and consequently the increase of the maturity index. This increase is also function of the appearance of other dark colours in the olives.

\section{CONCLUSION}

The evolution of the chemical composition of olives from the Moroccan Picholine can be divided into three stages. The first, which starts from the beginning of the fruit development until September, is characterised by the kernel development. The quotient of the weight of total fruit to weight of kernel is the lowest. During this stage the biosynthesis concerns mainly structural components. The lipogenesis is oriented towards the synthesis of the polar lipids.

From September the $15^{\text {th }}$ until the end of November, the mesocarp continues its development and an increase in the biosynthesis of neutral oil is observed mainly during November. 
The last stage (December $3^{\text {rd }}-$ January $2^{\text {nd }}$ ) is marked by a stability in the development of olives and in the composition and synthesis of the oil. Only the maturity index continues increasing. Neutral lipids show their maximal rates.

Then, the best period for harvesting olives in the Marrakech region would be the month of December. During this period olives contain their highest proportions of oil. But, variations could be observed from year to year depending on climatic conditions, agricultural techniques, and the alternance phenomenon.

\section{ACKNOWLEDGEMENTS}

The authors express their sincere gratitude to IFS (grant $\mathrm{N}^{\circ} \mathrm{E}$ 1480-1) and the AUPELF (LAF 313) organisations for supporting this research project. We gratefully acknowledge to the Dr. A. Cert, Head of the Analysis Department of Instituto de la Grasa Sevilla (Spain) for his helpful advice.

\section{REFERENCES}

A.F.NOR (1984).-— «Recueil de normes françaises des corps gras graines oleagineuses et produits derives".- $3^{\text {ème }}$ Ed.-AFNOR., Paris.

Aitzetmüller, K. (1989).- «Analysis of chlorophyll degradation products in fats and oilseeds".-Actes du congrès international "Chevreul»pour l'étude des corps gras.-Ed. ETIG., Paris.

Albat, M., Picot, B., Philipot, M. G., and Boutoux, J. (1982).- - Azote Kjeldahl, dosage acidométrique, détermination du point d'équivalence par
potentiométrie".-Revue Française des sciences de l'eau. 1, 359-369.

Alter, M. and Gutfinger, T. (1982).- «Phospholipids in several vegetable oils".-La Rivista Italiana Delle Sostanze Grasse. 59, 14-18.

Atouati, B. Y. (1991).- «Evolution des caractéristiques carpométriques et de la fraction phénolique totale avec le stade de maturité des olives, variété: Picholine marocaine".-Mémoire de $3^{\circ}$ cycle, IAV Hassan II, Rabat.

Di Giovacchino, L. (1991)._- «Situation en Italie de la voie enzymatique pour la production d'huile d'olive: résultats des essais et perspectives".-Rev. Fr. Corps Gras. 38, 85-94.

Kiritsakis, A. and Markakis, P. (1987).- «Olive oil: a review".-Advance in food research. 31, 453-482.

Loussert, R. et Brousse, G. (1978)._—L'olivier, Techniques agricoles et productions méditerranéennes».-Ed.-G. P. Maisonneuve et Larose., Paris.

M. A. M. V. A, (1996)._- «'oleiculture marocaine: situation actuelle et perspective d'avenir».-Le Pôle Alimentaire. 3, 14-17.

Marzouk, B. et Cherif, A. (1981).- «Lipogénèse dans l'olive I. Formation des lipides neutres".-Oléagineux. 36, 77-82.

Mínguez-Mosquera, I. M., Gandul-Rojas, B., Garrido-Fernández, J. and Gallardo-Guerrero, L. (1990).-_ «igments present in virgin olive oil».-J. Am. Oil Chem. Soc. 67, 192-196.

Poli, M. (1986). - «L'alternance de la production de l'olivier».-Olivae. 12, 7-27.

Walali, L. D., Chmitah, M., Loussert, R., Mahhou, A. et Boulouha, B. (1984).- - "Caractères morphologiques et physiologiques de clones d'olivier Picholine marocaine".Olivae. 3, 26-30.

Wolff, P. J. (1968).- «Manuel d'analyse des corps gras».-Ed.-AZOULAY., Paris. 